* Mestre em Direito pelo Centro Universitário Eurípides de Marília - SP (UNIVEM). Bolsista CAPES/PROSUP. Pós-graduando em Direito do Trabalho e Previdenciário pela Pontifícia Universidade Católica de Minas Gerais (PUC-MG). Membro dos Grupos de Pesquisas NEPI - Núcleo de Estudos e Pesquisas em Direito e Internet e DIFUSO - Direitos Fundamentais Sociais, ambos cadastrados no diretório de grupos de pesquisa do CNPQ. Advogado. E-mail: guilherme.luca@uol.com.br.

** Doutor em Direito pela Instituição Toledo de Ensino (ITE). Mestre em Direito pela Pontifícia Universidade Católica de São Paulo (PUC-SP). Professor e graduado em Direito pelo Centro Universitário Eurípides de Marília - SP (UNIVEM). Vice Coordenador do Programa de Mestrado em Direito Centro Universitário Eurípides de Marília - SP (UNIVEM). Líder do Grupo de Pesquisa DIFUSO - Direitos Fundamentais Sociais, cadastrado no diretório de grupos de pesquisa do CNPQ. Advogado.E-mail: teofilo@arealeao. com.

\section{MINHA CASA, MINHA VIDA: EXTENSÃO DO DIREITO À MORADIA E PROTEÇÃO CONSTITUCIONAL}

\author{
MINHA CASA, MINHA VIDA: THE EXTENSION \\ OF THE RIGHT TO HOUSING AND \\ CONSTITUTIONAL PROTECTION
}

\author{
*Guilherme Domingos de Luca \\ *Teófilo Marcelo de Arêa Leão Júnior
}

Resumo: O trabalho em questão busca analisar o Direito à moradia sob a ótica do Programa "Minha Casa, Minha Vida". Demonstrará as ações do Estado visando a Regularização Fundiária, em face do interesse social no combate ao déficit imobiliário, além de analisar as hipóteses de perda do imóvel. O objetivo geral do estudo é compreender se há efetividade no direito à moradia a partir da vinculação ao Programa "Minha Casa, Minha Vida", instituído pelo advento da Lei $\mathrm{n}^{\circ} 11.977 / 09$. De forma específica, o objetivo será entender o direito do indivíduo em adquirir novo imóvel, mesmo que em determinado momento teve de dispor de outro imóvel adquirido pelo Programa em questão. Trata-se de uma pesquisa pautada no método de investigação dedutivo, cujos procedimentos técnicos adotados foram livros, doutrinas, leis e jurisprudência. Com efeito, parte-se de um estudo bibliográfico e jurídico, para a posterior abordagem do atual contexto legislativo brasileiro mediante a adoção de um ponto de partida constitucional.

Palavras-chave: Moradia. Políticas Públicas. Regularização Fundiária. Minha Casa, Minha Vida. Constituição.

Abstract: This study intends to analyze the right to housing, from the perspective of the Program "Minha Casa, Minha Vida". It also aims to demonstrate the State's actions to Land Regularization against social interest in order to fight the housing deficit, in addition to analyzing property loss assumptions. The overall objective of this paper is to understand if there is any effectiveness in the right to own a home provided by the Program "Minha Casa, Minha Vida", established by enactment of Law No. 11,977/09. Specifically, the purpose of this study is to understand an individual's right to acquire new property, even if at some point he/she had to give away another property acquired by the program. This is a research guided by the deductive reasoning of investigation, and the 
technical procedures adopted were books, doctrines, laws and jurisprudence. Firstly, this study focuses on bibliographic and legal studies, advancing later to focus on the current Brazilian legal issues by adopting a constitutional point of departure.

Keywords: Housing. Public Policy. Regularization. Minha Casa, Minha Vida. Constitution.

Como citar: LUCA, Guilherme Domingos de; LEÃO JÚNIOR, Teófilo Marcelo de Arêa. Minha casa, minha vida: extensão do direito à moradia e proteção constitucional. Scientia Iuris, Londrina, v. 20, n. 1, p. 79-71, abr. 2016. DOI: $10.5433 / 2178-8189.2016 v 20 n 1 p 79$. ISSN: 2178-8189. 


\section{INTRODUÇÃO}

O trabalho em questão busca analisar o Direito à moradia sob a ótica do Programa Governamental brasileiro denominado "Minha Casa, Minha Vida".

Trata-se de uma Política Pública que visa combater o grande déficit imobiliário ainda existente no Brasil, atrelada à necessidade de efetivação dos direitos e garantias sociais previstos na redação do Artigo $6^{\circ}$ da Constituição Federal Brasileira.

O direito à moradia é um direito social dotado de inalienabilidade, irrenunciabilidade e imprescritibilidade, mas, em decorrência de inúmeras razões, ainda encontra-se distante da plena efetivação.

Diante desse contexto, fazem-se necessárias as ações do Estado na busca pela Regularização Fundiária, em face do interesse social. Ademais, a regularização fundiária está relacionada justamente à atividade a ser executada pelo Poder Público, no combate ao déficit imobiliário.

O Programa "Minha Casa, Minha Vida" tem se demonstrado, conforme será apresentado, como instrumento de regularização fundiária de interesse social no Brasil, razão pela qual justifica a sua análise, além de serem apresentados quais os requisitos necessários para fazer jus ao Direito.

Após apresentadas às mencionadas informações, o trabalho compreenderá a análise da carência do imóvel adquirido no "Programa Minha Casa, Minha Vida". Serão, portanto, interpretadas as formas de perda do imóvel por descumprimento contratual, seja mediante venda/alienação, seja até mesmo por inadimplemento.

Feitas essas considerações, o trabalho se findará na compreensão acerca do direito de aquisição de um novo imóvel para o titular que em determinado momento dispõe do seu bem, ante as causas anteriormente explanadas, além de destacar as soluções para efetivação do direito à moradia.

Com isso, verifica-se que o objetivo geral do estudo, é compreender se há efetividade no direito à moradia a partir da vinculação ao Programa Minha Casa, Minha Vida, instituído pelo advento da Lei n 11.977/09. De forma específica, o objetivo será analisar o direito do indivíduo em adquirir nova moradia, já que em determinado momento, por alguma razão, teve que dispor de outro imóvel adquirido por meio do Programa em foco.

Trata-se de uma pesquisa pautada no método de investigação dedutivo, 
cujos procedimentos técnicos adotados foram livros, doutrinas, leis e jurisprudência.

Com efeito, parte-se de um estudo bibliográfico e jurídico, para posterior abordagem do atual contexto legislativo brasileiro mediante a adoção de um ponto de partida constitucional.

\section{POLÍTICAS PÚBLICAS E DÉFICIT HABITACIONAL}

Antes de suscitar qualquer consideração acerca das Políticas Públicas e a questão que envolve o déficit habitacional no Brasil, aponta-se para a análise do direito à moradia, previsto na Constituição Federal Brasileira e ressalta-se que se trata de uma garantia fundamental do ser humano, consagradora do princípio da dignidade da pessoa humana.

Não se trata apenas do direito à moradia, mas sim, reconhece-se o Direito à moradia digna, já que é notória a busca do homem a um lugar para sobreviver, se instalar e poder se deleitar e proclamar possuir uma residência.

Há de se considerar que a moradia digna que o homem busca a cada dia é aquela levada em alta conta por ser dotada de proteção; proporcionar a satisfação individual dos moradores, tais como conforto; estar apta para nela sobreviver, não se enquadrando as moradias inadequadas, perigosas, insalubres, etc.; há de ser adequada ao espaço onde o indivíduo mantém suas atividades; além de benéfica para a sua existência e manutenção. Ora, uma moradia onde o proprietário sequer consegue pagar suas obrigações, não pode ser elevada ao grau de adequada.

O referido direito à moradia, consiste na posse, de forma exclusiva, com duração razoável, de um espaço onde se tenha proteção, além de resguardo ao direito de intimidade e de práticas essenciais para a vida.

Nesse sentido, moradia é o lugar íntimo de sobrevivência do ser humano, é o local privilegiado que o homem normalmente escolhe para alimentar-se, descansar e perpetuar a espécie. Constitui o abrigo e a proteção para si e os seus; daí nasce o direito à sua inviolabilidade e a constitucionalidade de sua proteção (NOLASCO, 2008, p. 88).

Diante desse contexto, percebe-se ao observar o artigo $6^{\circ}$ da Constituição 
Federal brasileira, após alteração originada de duas Emendas Constitucionais de 26, de 14.02.2000, e 64, de 04.02.2010, que o direito à moradia foi inserido no rol de direitos sociais:

São direitos sociais a educação, a saúde, a alimentação, o trabalho, a moradia, o lazer, a segurança, a previdência social, a proteção à maternidade e á infância, a assistência aos desamparados, na forma desta Constituição (BRASIL, 1988, p. 5 ).

Imperioso dizer que o artigo $6^{\circ}$ da Constituição Federal, conforme acima transcrito, traz em seu bojo inúmeros comandos direcionados ao próprio Estado, visto que cabe a ele a efetivação dos direitos sociais descritos.

Assim, a moradia, inserida no rol da presente norma, constitui também uma necessidade fundamental do homem, tendo como características a sua inalienabilidade, irrenunciabilidade e imprescritibilidade, cabendo ao Estado assegurá-la, em razão da dignidade da pessoa humana (ROMANELLI, 2007, p. 54).

Além disso, cumpre consignar que a dignidade da pessoa humana traz ao homem valores que deverão ser agregados à sua vida, "valores esses instituídos pela sociedade em que vive bem ou por si próprio, que o Estado pode e consegue muitas vezes reconhecer" (POZZOLI, 2014, p. 146).

$\mathrm{O}$ direito à moradia é um direito social que brota da natureza moral da pessoa humana, sendo um direito simplesmente pelo fato de o homem ser humano. Cuida-se de um direito de igualdade, importante para a vida, o qual deve ser dotado de plena efetividade.

Para que esteja de forma efetiva amparado pelo artigo $6^{\circ}$ da Constituição Federal, no que tange o direito de morar, não basta apenas que o ser humano possua uma moradia dotada de teto e paredes: "A diretiva constitucional determina que seja uma habitação digna, com um mínimo de conforto e salubridade" (AINA, 2009, p. 68).

Porém, mesmo havendo uma previsão Constitucional assegurando o direito à moradia no Brasil, as políticas públicas abrangidas na temática ainda se mostram ineficazes.

Muitos podem considerar a afirmativa anterior como equivocada, todavia as estatísticas comprovam que no país, mesmo após o advento da Política Pública 
denominada como "Minha Casa, Minha Vida", que será tratada adiante, não satisfaz ao reconhecimento da plena moradia, visto que a redução do déficit habitacional, no último ano, foi abaixo do esperado.

Por políticas públicas, entende-se tratar do campo dentro do estudo da política que analisa o governo à luz de grandes questões públicas. A definição mais célebre e enigmática acerca do assunto é de Laswell (1936), no sentido de que se tratam de decisões e análises sobre política pública, as quais implicam em responder às seguintes questões: Quem ganha? O quê? Por quê? E que diferença faz?

Em linhas gerais, definem-se as políticas públicas como:

Política pública como o campo do conhecimento que busca, ao mesmo tempo, "colocar o governo em ação" e/ou analisar essa ação (variável independente) e, quando necessário, propor mudanças no rumo ou curso dessas ações (variável dependente). A formulação de políticas públicas constitui-se no estágio em que os governos democráticos traduzem seus propósitos e plataformas eleitorais em programas e ações que produzirão resultados ou mudanças no mundo real (SOUZA, 2006, p. 26).

Portanto, há que se perceber que as políticas públicas visam obrigar o governo a praticar algo em favorecimento da população por ele governada. Os favorecimentos ocorrem a partir do momento em que o Estado, na figura de seu representante, traduz, de modo geral, suas propostas eleitorais em programas e ações que se almeja resultado na realidade. O programa "Minha Casa, Minha Vida" pode ser considerado um importante exemplo dessas políticas, criado pelo Governo Federal.

No que tange o direito de moradia, o referido programa - assim como tantos outros ao longo da história -, tem por objetivo principal a redução do chamado "déficit habitacional":

O déficit habitacional refere-se às moradias que devem ser construídas seja para substituir os domicílios existentes que não apresentam as condições de segurança indispensáveis a seus ocupantes, seja para garantir habitação adequada 
às famílias que não têm um domicílio de uso privativo (GENEVOIS; COSTA, 2001).

Desta forma, o déficit habitacional está relacionado ao número de moradias que ainda devem ser construídas no Brasil, para que então o "direito constitucional à moradia" seja efetivamente inserido e consagrado na sociedade.

Segundo dados levantados pela Fundação João Pinheiro, em parceria com o Ministério das Cidades, a partir do censo de 2010 e publicado em novembro de 2013, no Brasil, até então, há um déficit de 6940 milhões de unidades, sendo 85\% na área urbana (FUNDAÇÃO JOÃO PINHEIRO, 2013).

Percebe-se, portanto, que, no Brasil, o número de pessoas que não possuem uma residência ainda é bastante elevado, mesmo havendo políticas públicas voltadas ao direito de moradia, previsto na Constituição Federal. Trata-se de um dos maiores problemas brasileiros, agravado até mesmo pela inexistência de recursos públicos capazes de solucionar o acesso à população de baixa renda.

Alguns fatores são levados em consideração, para calcular o déficit habitacional, tais como habitações precárias ou domicílios improvisados, coabitação familiar, ônus excessivo com aluguel, adensamento excessivo nos domicílios alugados e problemas de legalidade fundiária urbana (LEÃO JÚNIOR, 2014, p. 80).

Quando tais fatores são evidenciados dentro da sociedade, aponta-se para a extrema necessidade de melhoria na infraestrutura e regularização fundiária, visto que a população sequer preenche os requisitos fundamentais para conseguir financiar a casa própria, exceto na possibilidade de se enquadrar dentro de uma política pública capaz de solucionar a controvérsia.

Com isso, não restam dúvidas do papel do Estado e das políticas públicas, visando diminuir o déficit habitacional. Fala-se, portando, da regularização fundiária, como forma de intervenção dos entes públicos, no resguardo dos direitos de cidadania, das pessoas que vivem em áreas desprotegidas.

\section{REGULARIZAÇÃO FUNDIÁRIA E INTERESSE SOCIAL}

No tópico anterior, demonstrou-se o direito social a moradia, bem como o papel do Estado na efetivação do respectivo Direito.

Por outro lado, ainda se evidenciou que o déficit habitacional até hoje é 
uma realidade que persiste na vida de inúmeros brasileiros.

Entretanto, diante do cenário apontado, há de se investigar de modo livre e aberto acerca da chamada regularização fundiária, que é o "nome dado aos programas de intervenção pública que visam resgatar os direitos de cidadania das populações residentes em áreas urbanas degradas" (GAZOLA, 2008, p. 117).

Diante dessas considerações, percebe-se que a regularização fundiária está relacionada à atividade a ser executada pelo Poder Público, sendo um "processo de intervenção pública, regularização jurídica, urbanística, espacial e social” (ROMANELLI, 2007, p. 107).

A razão justificadora da regularização fundiária deve-se, muitas vezes, em razão da propriedade do solo, na sua maioria, ser de cunho privado, cabendo, por isso, ao Poder Público regulamentar seu uso e apropriação, a partir de imposição de limites e regras de cunho privado, para o exercício do direito individual da propriedade.

Entretanto, há de se destacar que a regulamentação jurídica não deve ser desconsiderada. O morador titular de um terreno, lote ou terra, possui plenamente o exercício e gozo dos seus direitos. Assim, a norma jurídica o protege, no sentido de que o possuidor só terá direito pleno se obtido o título de propriedade, o que gera na mente do morador segurança derivada da garantia de que não irá perder sua propriedade por motivo vão, sem força jurídica necessária:

A proteção que o possuidor só teria, com o título de propriedade, gera no espírito do morador a garantia de não perder sua propriedade por motivo vão, ou sem força jurídica bastante, proporcionando-lhe segurança, possibilitando a realização de acessões e benfeitorias em seu imóvel e a exploração socioeconômica, além da possibilidade de tomar crédito em instituições públicas e privadas, pelo fato de ter patrimônio como garantia. A regularização jurídica faz cessar a ameaça ao exercício da posse e do direito de propriedade (LEÃO JÚNIOR, 2014, p. 90).

Nesse contexto, visto que a Regularização Fundiária consiste em conferir o título de propriedade, quem já possui seu bem imóvel, terá resguardado todos os seus direitos, exceto se, na conformidade do Direito, demonstre-se que o direito de propriedade tenha sido utilizado de forma contrária a lei. 
Nota-se que a Administração Pública exerce importante papel na inserção da Regularização Fundiária no contexto social, em especial na regularização urbanística, do ambiente e na esfera social.

A fundamentação jurídica acerca do conceito de Regularização Fundiária encontra-se respaldada na Lei 10.257/01, conhecido como Estatuto da Cidade, bem como na Lei 11.977/09, que instituiu o Programa "Minha Casa, Minha Vida", nos termos dos artigos $2^{\circ}$, XIV, e 46, respectivamente.

Com a referida alteração normativa, houve consecutivamente a regulamentação dos artigos 182 e 183 da Constituição Federal Brasileira, estabelecendo diretrizes gerais para a execução de políticas urbana e regularização fundiária dos assentamentos localizados nas áreas urbanas.

Há de se falar ainda no Projeto de Lei $n^{\circ} 3.057 / 00$ (artigo $2^{\circ}$, II), de autoria do Bispo Wanderval, e que se encontra na mesa Diretora da Câmara dos Deputados desde 05.03.2008, que pretende alterar a Lei 6.776/79, no que tange à conceituação de Regularização Fundiária Sustentável:

[...] o conjunto de medidas jurídicas, ambientais e sociais, promovidas pelo Poder Público por razões de interesse social ou de interesse específico, que visem a adequar assentamentos informais preexistentes às conformações legais, de modo a garantir o direito social à moradia, o pleno desenvolvimento das funções sociais da propriedade urbana e o direito ao meio ambiente ecologicamente equilibrado (BRASIL, 2000, p. 41 ).

Com isso, percebe-se que a Regularização Fundiária Sustentável busca discorrer das Políticas Públicas de forma multidisciplinar, hábil, bem como oferecer emancipação econômica e social aos beneficiários.

Os programas de Regularização Fundiária, de modo geral, apenas remediam o problema habitacional que ocorre no Brasil. De qualquer modo, seu papel é o de levar a moradia ao maior número de pessoas da sociedade, visando o fim da informalidade e efetivação do objetivo Constitucional.

Diante deste cenário, há de se destacar a Regularização Fundiária de Interesse Social, determinada no artigo $3^{\circ}$, da Lei 11.977/09, que prevê quem são os beneficiários do Programa "Minha Casa, Minha Vida", dentro de determinadas prioridades.

No caso em comento, a Lei que instituiu referida Regularização Fundiária 
de interesse social, além de garantir aos beneficiários o direito à habitação digna, conferiu ainda, condições aos beneficiários da Política Pública, para se manter com sua família e terem acesso a todos os bens e serviços (LEÃO JÚNIOR, 2014, p. 95).

Com isso, segundo a redação normativa, aos beneficiários do referido Programa é assegurado o acesso aos bens e serviços como trabalho, emprego, escolas, creches, bem como às demais Políticas Públicas que com esta tiverem relação.

Portanto, a partir da concretização de Regularização Fundiária de Interesse Social, percebe-se a existências de poderes em face da Administração Pública, na promoção da justiça e correção das desigualdades econômicas, de modo que a cidade se torne um ambiente sustentável e de plena promoção ao direito pleno de moradia digna.

Dentro desse contexto, à luz da legislação vigente, quis o legislador ofertar ao administrador o maior controle dos administrados, quanto ao uso e ocupação, parcelamento do solo e até na preservação ambiental, fazendo com que o espaço urbano construído, seja aproveitado da melhor forma possível.

Analisando a Lei que instituiu o Programa "Minha Casa, Minha Vida", percebe-se que houve maior permissão ao Poder Público no estabelecimento de critérios para aprovação de projetos que visassem à referida Regularização Fundiária nos denominados "assentos irregulares", nas terras públicas ou particulares, para que assim houvesse uma otimização nas ações integradas em face da demanda local por moradia, a partir da realidade social. Essa realidade se constata dentro da análise da rua, bairro e município, tudo isso atrelado aos aspectos econômicos (BRASIL, 2009).

No que tange à Regularização Fundiária, justamente por se tratar de interesse social, há maior atenção em atender as pessoas denominadas "carentes", atingindo, assim, a sua finalidade social.

Merece destaque a Portaria 610, de 26.12.2011, do Ministério das Cidades, a qual estabeleceu cotas como novos critérios e procedimentos para priorização dos benefícios do Programa "Minha Casa, Minha Vida", oferecendo $3 \%$ das unidades habitacionais aos idosos, bem como o mesmo percentual às pessoas com deficiência ou suas famílias, desde que não haja percentual superior previsto em Lei Municipal ou Estadual (BRASIL, 2011).

Conforme demonstrado, o Programa "Minha Casa, Minha Vida", instituído por força da Lei 11.977/2009, é o principal exemplo de Regularização 
Fundiária, de interesse social, nos dias atuais. Por tais razões, faz-se necessário destacar a importância do Programa no espaço social.

\section{PROGRAMA MINHA CASA, MINHA VIDA, COMO INSTRUMENTO DE REGULARIZAÇÃO FUNDIÁRIA}

Imperioso dizer que o Programa "Minha Casa, Minha Vida", tornou-se o principal instrumento de Regularização Fundiária de interesse social no Brasil.

A sua finalidade, conforme previsto no artigo $2^{\circ}$, da Lei $11.977 / 2009$, que implantou o programa, demonstra haver criado mecanismos de incentivo à produção e à aquisição de novas unidades habitacionais pelas famílias com renda mensal de até dez salários mínimos, residentes em todo o território Nacional (BRASIL, 2009).

O programa em questão, refere-se a um conjunto de soluções que visam resolver os problemas de déficit habitacional no Brasil, cuja instituição visou abranger o Programa Nacional de Habitação Urbana e o Programa nacional de Habitação Rural.

O objetivo principal do Programa "Minha Casa, Minha Vida", além de pretender diminuir o déficit habitacional, visa implantar subsídios governamentais a serem utilizados pelas famílias de baixa renda, tanto nas áreas urbanas como nas áreas rurais.

É certo que a Lei em comento recomenda também a criação de Políticas Públicas, com o objetivo de proporcionar bem-estar e sustentabilidade aos municípios. , merece serem destacados os principais pontos que o Programa "Minha Casa, Minha Vida" tem por objetivo desde a sua criação:

a) Os problemas de infraestrutura e saneamento básico das residências existentes, ao combater o déficit por reposição de estoque, via concessão de subsídios às famílias. b) Regularizar a questão fundiária das moradias em terrenos invadidos ou em áreas públicas, pela diminuição do valor de custas/ emolumentos cartorários ou da exigência de legalização de matrículas nos cartórios de registro de imóveis, com a preferência pelo registro do imóvel no nome da mulher. c) Aumentar a oferta de unidades habitacionais, facilitando o acesso aos recursos do BNDES e dos fundos instituídos 
pelo PMCMV por parte das construtoras, visando diminuir o déficit por incremento de estoque. d) Eliminar a "elitização" dos financiamentos imobiliários ao conceder subsídios às classes sociais mais pobres, sobretudo aquelas com renda mensal de até três salários mínimos e que em geral não têm acesso aos recursos do FGTS. e) Resolver os aspectos técnicos da construção de novas moradias, ao determinar padrões de construção, impor limites para a construção de unidades habitacionais por empreendimento e exigir uma infraestrutura urbana mínima para aprovação dos projetos e liberação dos recursos (D'AMICO, 2011, p. 47).

Nesse contexto, nota-se que todos os pontos tratados pela Lei 11.977/09 encontram-se fundamentado, principalmente, na questão do déficit habitacional, buscando satisfazer a todos quanto ao direito pleno a moradia, regularização da falta de infraestrutura e saneamento básico, aumentando a oferta habitacional e o alcance aos recursos disponíveis, bem como procura eliminar a denominada elitização de financiamentos imobiliários, que até então era tratado como uma inerência aos mais favorecidos.

Por outro lado, há quem discorde da criação da norma mencionada, afirmando que o Programa "Minha Casa, Minha Vida", sob uma política de cunho mercadológico, teria sido criado com o objetivo apenas de satisfazer transações econômicas do mercado, aquecendo sobretudo o setor imobiliário e da construção. Aceita-se que o Programa tornou-se uma política para "estimular o setor da construção civil, tradicionalmente um setor que emprega grande quantidade de mão de obra de baixa qualificação e que tem uma grande participação no PIB do país" (D’AMICO, 2011, p.47):

Assim o Programa Minha Casa Minha Vida, ganhou enorme evidência em relação à política de regularização fundiária urbana pelo seu cunho mercadológico, com finalidade de criar mecanismos de incentivo à produção e aquisição de novas unidades habitacionais ou requalificação de imóveis urbanos e produção ou reforma de habitações rurais para famílias com renda mensal de até $\mathrm{R} \$ 4.650,00$ (quatro mil, seiscentos e cinquenta reais), compreendendo os seguintes subprogramas: 
Programa Nacional de Habitação Urbana - PNHU; e Programa Nacional de Habitação Rural - PNHR (MENDES, 2013, p. 8).

Percebe-se também que o Programa "Minha Casa, Minha Vida" exerceu importante impacto na política atual. Foi matéria, inclusive, de debates durante nas últimas eleições Presidenciais do ano de 2014.

Não obstante, trata-se de instrumento para uma Regularização Fundiária de Interesse Social, que foi usada tanto para aquecer a economia imobiliária e da construção como também é uma forma de ofertar acesso à moradia às pessoas consideradas de baixa renda, dentro dos critérios legais estipulados.

Segundo levantamentos publicados pelo Ministério do Planejamento, do período compreendido entre 2009 até o final de 2013, já haviam sido contratados mais de dois milhões de moradias por meio do Programa "Minha Casa, Minha Vida", sendo que 1,4 milhões de residências já haviam sido entregues (BRASIL, 2013).

Vale ressaltar que o objetivo central dessas Políticas Públicas é proporcionar ao cidadão o acesso à moradia, conforme previsão do caput do artigo $6^{\circ}$, da Constituição Federal. Assim, deve ser diferenciado o acesso à moradia do acesso ao título imobiliário.

À luz da Lei 11.977/09, para que o cidadão tenha direito de participar do Programa, deverá se enquadrar dentro de determinadas faixas de rendas previstas, para investimentos previamente estipulados, sendo que a seleção dos beneficiários será de responsabilidade dos Municípios. Quanto aos recursos, estes são originados dos orçamentos do Ministério das Cidades, repassados para a Caixa Econômica Federal, que atua como agente operacional do programa (BRASIL, 2009).

O Programa "Minha Casa, Minha Vida", sem dúvida alguma, é um modelo de Regularização Fundiária Social, efetivada pelo Estado. Caso ocorra omissão na sua execução, o Judiciário deve ser provocado, como forma de estabelecer cronogramas e assegurar o direito social à moradia digna.

Após a conquista deste direito, cabe ao seu titular adequar-se a todas as exigências legais, desde o de respeitar a função social da propriedade, como também ao cumprimento das obrigações, para assim poder usar, gozar e dispor, corretamente, nos termos do artigo 1.228 do Código Civil.

Por outro lado, aquele titular do direito à moradia que não agir de forma adequada, poderá perder seu bem, ou agindo corretamente, poderá dele dispor, 
conforme pautado na norma Civil.

\section{CARÊNCIA DO IMÓVEL ADQUIRIDO NO PROGRAMA MINHA CASA, MINHA VIDA}

Depois de cumprido os requisitos previstos na redação da Lei 11.977/09, para fazer jus ao benefício do Programa "Minha Casa, Minha Vida", o titular do imóvel, que terá acesso à moradia, torna-se titular de direitos e deveres. Uma vez exercido esse direito de forma legal, o imóvel terá titularidade exclusiva, cabendo ao proprietário todas as proteções previstas pela norma jurídica.

Por outro lado, uma vez descumpridas as regras previamente estabelecidas pelo Programa, tais como o descumprimento de cláusula contratual pertinente, como inadimplemento, desvio de finalidade do imóvel, bem como a alienação, tratando-se de imóvel já adquirido, surgirá a possibilidade de perda do Direito Constitucional à moradia.

Há de se consignar que na referida Política Pública, o imóvel é dado como garantia de pagamento ao financiamento feito junto à instituição financeira. Assim, o titular do bem pode morar na casa com a família, durante toda a vigência do contrato, mas não pode vender, alugar ou deixar de pagar as prestações ou descumprir as regras, até que o contrato dessa casa termine ou seja pago todo o valor devido (BRASIL, 2015).

Vale reiterar que a "Minha Casa, Minha Vida" é uma Política Pública que visa oferecer moradia para aquele que até então não detém um lugar para morar. Assim, mostra-se incoerente o Programa ao prestigiar aqueles que possuem apenas o desejo econômico, tais como objetivem somente obter aluguel ou revender o bem obtido.

Por sua vez, no que diz respeito à venda, os beneficiários das denominadas faixas de renda 2 e 3 , por serem operações de mercados, nada impede a venda, diferente aos de faixa de renda 1 , considerada a classe mais baixa.

A Política Urbana do Programa governamental deve privilegiar, na sua essência, aqueles que não possuem qualquer tipo de imóvel:

Ao Poder Público atribui-se a incumbência de implantar e desenvolver política habitacional e urbana, a fim de remover o quadro de desigualdade social e territorial nas cidades. A esses grupos informais vulneráveis deve-se desenvolver 
política urbana inclusiva prevista na legislação, no Estatuto da Cidade, em especial no Plano Diretor Municipal (LEÃO JÚNIOR, 2014, p. 101).

Desse modo, as ações afirmativas do Estado, as quais visam combater o déficit habitacional, não compartilham da ideia de se obter lucros a partir do benefício concedido à população. Com isso, havendo uso indevido deste imóvel, tal como aluguel ou aquisição para venda, não há razão para o beneficiário se manter em condição privilegiada, atendidas pelos critérios inseridos na Lei ${ }^{\circ}$ 11.977/09, podendo o Estado antecipar a exigência da dívida financiada e impor sanções, conforme previsão dos artigos a seguir:

Art. 7o Em casos de utilização dos recursos de que tratam os incisos I, II e III do art. 2o em finalidade diversa da definida nesta Lei, ou em desconformidade ao disposto nos arts. 6o, 6o-A e 6o-B, será exigida a devolução ao erário do valor da subvenção concedida, acrescido de juros e atualização monetária, com base na remuneração dos recursos que serviram de lastro à sua concessão, sem prejuízo das penalidades previstas em lei (BRASIL, 2009).

Art. 14. Em casos de utilização dos recursos de que trata o art. 11 em finalidade diversa da definida nesta Lei, ou em desconformidade ao disposto no art. 13, será exigida a devolução ao erário do valor da subvenção concedida, acrescido de juros e atualização monetária, com base na remuneração dos recursos que serviram de lastro à sua concessão, sem prejuízo das penalidades previstas em lei (BRASIL, 2009).

Ora, a previsão estipulada em lei, por meio dos dispositivos transcritos, evidencia a correta punição para aquele que desvirtua a finalidade do Programa "Minha Casa, Minha Vida", objetivando a obtenção de lucros. A razão que justifica a quebra contratual, nessa hipótese, é a aplicação do princípio da "boa-fé".

É certo que, nos contratos, a boa-fé deve ser consagrada, assim como nas demais relações jurídicas, "isto é, da lealdade, da confiança recíproca, da 
justiça, da equivalência das prestações, da coerência e clarividência dos direitos e deveres" (RIZZARDO, 2010, p. 32).

Há outra forma muito comum de carência do imóvel adquirido no referido programa. Versa sobre o inadimplemento das obrigações. Conforme previsão legal, tal fato pode ocasionar a quebra contratual e exigência antecipada das obrigações, a partir do momento em que o proprietário do imóvel deixa de pagar duas ou mais prestações (BRASIL, 2015).

Diante do exposto, há de se notar que o Estado, visando combater os problemas em razão da ausência de moradia, oferece meios para que a população tenha acesso a este direito fundamental.

Entretanto, muito embora esse direito seja considerado fundamental, há quem o classifica como subjetivo, ante ao fato de ser de baixa densidade, faltando forças para que produza efeitos imediatos, razão pela qual muitas vezes o titular abre mão do gozo e exercício do seu direito.

\section{MINHA CASA, MINHA VIDA E AQUISIÇÃO DE NOVO IMÓVEL ANTE A VEDAÇÃO NORMATIVA}

Conforme demonstrado no tópico anterior, a Lei 11.977/09 permite ao titular do Benefício do Programa Habitacional Minha Casa, Minha Vida, dispor de seu imóvel. Prevê ainda, situações onde o titular poderá perder o seu bem, de forma involuntária, ante ao não cumprimento de normas e regras contratuais.

Além do mais, aquele que perdeu o imóvel não poderá adquirir outro imóvel com os descontos e as vantagens ofertadas pelo Programa "Minha Casa, Minha Vida" (BRASIL, 2015).

A partir de uma análise preliminar, percebe-se que o Estado visa assegurar a regularidade nos contratos firmados a partir do benefício concedido pela Política Pública. Porém, há que se notar que em caso de o titular dispor do imóvel por culpa do adquirente, este não mais terá direito a novo benefício.

Diante disso, pondera-se que a rigidez da norma quanto à necessidade de se cumprir o contrato se apresenta em decorrência da urgência em se reduzir o déficit habitacional, que, mesmo nos dias atuais, mostra-se elevado, conforme já mencionado.

Todavia, há de se enfrentar a seguinte situação: muito embora o titular do bem tenha dele disposto, seja pela venda ou em razão da quebra contratual decorrente do inadimplemento das obrigações, o seu direito fundamental à 
moradia permanece inalienável, irrenunciável e imprescritível, uma vez que se encontra resguardado na redação do artigo $6^{\circ}$, da Constituição Federal. Assim, mesmo que o titular tenha se desfeito de determinado bem derivado do Programa, o direito à moradia digna se mantém.

Desta forma, a partir do momento em que a Lei, ao apresentar as diretrizes do Programa, limita o acesso das pessoas, obstando-as a que consigam atingir a finalidade do primeiro contrato, as quais não conseguirão celebrar, portanto, outro contrato, está impedindo o acesso ao direito fundamental de moradia.

Ocorre, conforme já mencionado no tópico anterior, que parte da doutrina jurídica classifica os direitos sociais, como direitos subjetivos. Assim, posto que o direito à moradia é um direito social, também será considerado como um direito subjetivo.

Aponta-se, para a classificação dos direitos levantada por Canotilho (2003, p.476), que, ao discorrer acerca dos direitos sociais em suas dimensões subjetivas e objetivas, entende que eles geram autênticos direitos subjetivos, inerentes ao espaço existencial do cidadão, independente da sua justicialidade e exequibidade.

Ademais, há quem considere os direitos sociais como de baixa densidade. Faltam-lhes, pois, força para que produzam efeitos imediatos, que muitas vezes são supostos ou esperados pelos menos avisados. A partir do momento que se identifica a dimensão objetiva e subjetiva dos direitos sociais, aponta-se para a revelação de suas formas:

Imposições legiferantes, apontando para a obrigatoriedade o legislador acturar positivamente, criando as condições materiais e institucionais para o exercício desses direitos; e fornecimento de prestações aos cidadãos, densificadoras da dimensão subjectiva essencial destes direitos e executoras do cumprimento das imposições institucionais (CANOTILHO, 2003, p. 476).

Desde o momento em que a Carta Constitucional estabeleceu de forma objetiva um determinado direito social, criou-se o dever imposto ao legislador ordinário de, em cumprimento da norma constitucional, agir quer positivamente, quer negativamente,

$\mathrm{O}$ agir positivamente se verifica se e quando ao se implantar a norma, 
material e concretamente em consonância com a redação constitucional, por outra lei ou pelas Políticas Públicas capazes de implementá-las.

Quanto ao agir negativamente, acontece quando há a relação de dever geral de abstenção, individual e coletivo, para que nenhuma norma infraconstitucional contrarie o comando Constitucional, sob pena de ser declarada, consecutivamente, inconstitucional.

No que tange ao direito à moradia, não há na Constituição nenhuma norma que estabeleça como sendo um direito público subjetivo. Contudo, há inúmeras normas de atribuição de competência. Ainda que se trate de um direito de baixa densidade, as normas previstas nos artigos 21 e 23 da Constituição autorizam que o particular, particulares ou até mesmo os grupos de pessoas lesadas, atuem na proteção do direito à moradia, o que leva à conclusão da existência de um direito subjetivo.

Os direitos sociais, no caso o direito à moradia, embora apresentemse como direitos objetivos de baixa densidade, por se tratar de garantia fundamental, em caso de violação, emerge ao particular, o direito subjetivo, porquanto lhe é dado o poder de invocar a norma em seu favor. Os legitimados a determinada tutela em razão da violação do direito à moradia, poderão pleitear perante o próprio transgressor do direito social, seja pela via administrativa, seja pela via judicial.

Partindo-se para a seara do Programa "Minha Casa, Minha Vida", notase que, mesmo havendo uma previsão legal quanto à Política Pública que nega o acesso a novo benefício para aquele que dispôs do bem em determinado momento, ante seu direito objetivo à moradia, cabe a ele ainda exercer o seu direito subjetivo, que lhe abre a oportunidade de pleitear sua garantia constitucional a esse direito por meio judicial.

Nessa linha, cumpre consignar que não cabe à Lei Infraconstitucional vedar o acesso à moradia, em decorrência de um descumprimento por parte do proprietário do imóvel. Sabe-se que os contratos celebrados por meio de financiamento imobiliário, em especial pelo Programa "Minha Casa, Minha Vida", perduram ao longo de inúmeros anos. Neste período, muitos fatos jurídicos naturais ou fatos jurígenos podem acontecer, tais como a morte, o desemprego, um terremoto, uma enchente, uma revolução, ou qualquer outro tipo de crise econômico-financeira grave, enfim, um ou outro que venha a ensejar o inadimplemento e/ou descumprimento do pacto.

Não se mostra correta, além de exigência antecipada das obrigações 
do contrato, consecutiva quebra e perda do bem, com a proibição do antigo proprietário ter acesso a novo benefício, com evidente violação ao direito social, previsto no artigo $6^{\circ}$, da Constituição Federal.

\section{CONSIDERAÇÕES FINAIS}

Por direito à moradia, percebe-se tratar da posse, de forma exclusiva, com duração razoável, de um espaço onde se tenha proteção, além de resguardo ao direito de intimidade e de práticas essenciais para a vida. Trata-se de uma previsão Constitucional, que conforme já mencionada, está disposta na redação do artigo $6^{\circ}$ da Constituição Federal. Entretanto, a moradia prevista na redação Constitucional, além de ser constituída de teto e parede, deve possuir ainda garantias mínimas para que a sobrevivência do ser humano ocorra de forma digna.

Por outro lado, mesmo havendo uma positivação Constitucional, as estatísticas demonstram que o déficit imobiliário ainda é uma realidade persistente no ordenamento jurídico, razão pela qual justifica a inserção de Regularização Fundiária de interesse social, tal como ocorre com o Programa "Minha Casa, Minha Vida", inserido a partir do advento da Lei 11.977/2011.

Para que o cidadão tenha direito de participar deste Programa, que proporciona condições especiais para financiamento do imóvel, podendo o comprador se valer do próprio bem como garantia da dívida, deverá se enquadrar dentro de determinadas faixas de rendas previstas, para determinados investimentos, sendo que a seleção dos beneficiários será de responsabilidade dos Municípios.

Por outro lado, após a aquisição do imóvel, foi possível perceber ao longo da análise, que em determinadas hipóteses, tais como descumprimento contratual, inadimplência ou até mesmo por desvio de finalidade, poderá o proprietário perder o benefício da Política Pública, de modo que se antecipará a cobrança de todo o valor devido no contrato de financiamento, além da perda do subsídio.

A Lei 11.977/2011 expõe que aquele que perdeu o imóvel, não poderá adquirir outro imóvel com os descontos e vantagens ofertadas pelo Programa "Minha Casa, Minha Vida".

Todavia, a referida regra, muitas vezes, se mostra infringente ao texto Constitucional. Muito embora o titular tenha disposto do bem, seja por meio 
da venda, seja em razão da quebra contratual decorrente do inadimplemento das obrigações, o seu direito fundamental à moradia não pode ser excluído, permanece, pois, com seus atributos: inalienável, irrenunciável e imprescritível.

Há quem considera o direito à moradia como de baixa densidade, por faltar-lhe força para que produza efeitos imediatos, que, muitas vezes, tidos como supostos ou esperados pelos menos avisados. Todavia, imperioso dizer, que mesmo em se tratando de direito de baixa densidade, a sua proteção é regulada pela Constituição Federal. Em caso de violação, emerge ao particular o direito subjetivo, que é o poder de invocar a norma em seu favor. Os legitimados a determinada tutela em razão da violação do direito à moradia poderão pleitear perante o próprio transgressor do direito social, seja por via administrativa, seja por via judicial.

No que tange ao Programa "Minha Casa, Minha Vida", mesmo havendo uma previsão legal quanto à Política Pública que nega o acesso ao novo benefício para aquele que dispôs do bem em determinado momento, em razão da exigência de efetivação de um Direito Constitucional, ante ao seu direito objetivo à moradia, cabe a ele exercer a tutela subjetiva, podendo, assim, pleitear suas garantias na seara judicial.

Não cabe à Lei Infraconstitucional vedar o acesso à moradia, diante da ocorrência de um descumprimento por parte do proprietário do imóvel. Sabe-se que os contratos celebrados por meio de financiamento imobiliário, em especial pelo Programa "Minha Casa, Minha Vida", perduram ao longo de inúmeros anos. Neste período, variados fatos de efeitos jurídicos podem acontecer, tais como a morte, o desemprego, uma guerra civil, ou qualquer outro tipo de crise econômico-financeira grave, em suma, um ou outro que cause ou motive o inadimplemento e/ou descumprimento do contrato.

Por fim, conclui-se que não se mostra correta, além de exigência antecipada das obrigações do contrato, consecutiva quebra e perda do bem, proibir que o antigo proprietário tenha acesso ao novo benefício, sob a manifesta iminência de ocorrer violação ao direito social, previsto no artigo $6^{\circ}$ da Constituição Federal.

\section{REFERÊNCIAS}

AINA, Eliane Maria Barreiros. O fiador e o direito à moradia: direito 
fundamental à moradia frente à situação do fiador proprietário do bem de família. Rio de Janeiro: Lumen Juris, 2004.

BRASIL. Constituição (1988). Constituição da República Federativa do Brasil: promulgada em 5 de outubro de 1988. Disponível em: $<$ http://www. planalto.gov.br/ccivil_03/constituicao/constitui\%C3\%A7ao.htm>.Acesso em: 15 mar. 2015.

\section{. Lei 11.977 de 07.07.2009. Institui o Programa Minha Casa, Minha}

Vida. Disponível em: <http://www.planalto.gov.br/ccivil_03/_ato20072010/2009/lei/111977.htm>. Acesso em: 10 mar. 2015.

. Ministério do Planejamento. Minha Casa, Minha Vida já entregou 1,4 milhões de casas pelo país. Brasília, 09 dez. 2013. Disponível em: <www. pac.gov.br/noticia/22141600>. Acesso em: 10 mar. 2015.

. Poder Executivo. Ministério das Cidades. Portaria 610 de 26.12.2011. Disponível em: <http://www.cehap.pb.gov.br/arqs/legislacao/ original/201211141045100000009040.pdf $>$. Acesso em: 10 mar. 2015.

. Poder Legislativo. Câmara dos Deputados. Projeto de Lei 3.057 de 18 de maio de 2000. Disponível em: $<$ http://imagem.camara.gov.br/Imagem/d/ pdf/DCD25MAI2000.pdf\#page=89>. Acesso em: 20 mar. 2015.

CANOTILHO, José Joaquim Gomes. Direito constitucional e teoria da constituição. Coimbra: Almedina, 2003.

D’AMICO, Fabiano. O Programa Minha Casa Minha Vida e a Caixa Econômica Federal. In: COSTA, Juliana Camargos. O desenvolvimento econômico brasileiro e a Caixa. Rio de Janeiro: Centro Internacional Celso Furtado de Políticas para o Desenvolvimento, Caixa Econômica Federal, 2011.

\section{FUNDAÇÃO JOÃO PINHEIRO. Deficit habitacional municipal no Brasil} 2010. Belo Horizonte, 2013. Disponível em: <www.fjp.mg.gov.br/index. $\mathrm{php/docman/cei/deficit-habitacional/216-deficit-habitacional-municipal-no-}$ brasil-2010/file>. Acesso em: 10 mar. 2015. 
GAZOLA, Patrícia Marques. Concretização do direito à moradia digna: Teoria e prática. Belo Horizonte: Fórum, 2008.

GENEVOIS, Marie Louise Bulhões Pedreira; COSTA, Olavo Viana. Carência habitacional e déficit de moradias: Questões Metodológicas. São Paulo em Perspectiva, São Paulo, v. 15, n.1, p. 73-84, 2001.

LASWELL, Harold Dwight. Politics: who gets what, when, how. Cleveland, Meridian Books, 1936.

LEÃO JÚNIOR, Teófilo Marcelo de Arêa. Acesso à moradia: políticas públicas e sentença por etapas. Curitiba: Juruá, 2014.

MENDES, Christine Keler de Lima. Responsabilidade consumerista da instituição financeira pela qualidade das unidades habitacionais do Programa Minha Casa Minha Vida. In: XXII Encontro Nacional do CONPEDI, 2013, Curitiba. 25 Anos da Constituição cidadã: Os atores sociais e a concretização sustentável dos objetivos da República. Florianópolis: FUNJAB, 2013.

NOLASCO, Loreci Gottschalk. Direito fundamental à moradia. São Paulo: Pillares, 2008.

POZZOLI, Lafayette. Direito como função promocional: da dignidade humana ao direito fraterno. Revista Faculdade de Direito PUCSP, v. 2, p. 143-153, 2014.

RIZZARDO, Arnaldo. Contratos. 10. ed. Rio de Janeiro: Forense, 2010.

ROMANELLI, Luiz Claudio. Direito à moradia à luz da gestão democrática. 2. ed. Curitiba: Juruá, 2007.

SOUZA, Celina. Políticas públicas: uma revisão da literatura. Sociologias (UFRGS), Porto Alegre, v. 8, n.16, p. 20-45, 2006.

Como citar: LUCA, Guilherme Domingos de; LEÃO JÚNIOR, Teófilo Marcelo 
de Arêa. Minha casa, minha vida: extensão do direito à moradia e proteção constitucional. Scientia Iuris, Londrina, v. 20, n. 1, p. 79-71, abr. 2016. DOI: 10.5433/2178-8189.2016v20n1p79. ISSN: 2178-8189.

Submetido em 10/05/2015

Aprovado em 11/02/2016 